\title{
Epithelioid leiomyosarcoma of uterine cervix: A case report with immunohistochemical study
}

\author{
Tadashi Terada* \\ Department of Pathology, Shizuoka City Shimizu Hospital, Shizuoka, Japan
}

Received: December 30, 2015

Accepted: January 25, 2016

Online Published: February 24, 2016

DOI: $10.5430 /$ crcp.v3n1p69

URL: http://dx.doi.org/10.5430/crcp.v3n1p69

\begin{abstract}
Primary epithelioid leiomyosarcoma of uterine cervix (UC) has rarely been reported. A 90-year-old woman presented abnormal uterine bleedings. Colposcopy revealed erosions of cervix, and biopsy was taken. It showed proliferation of atypical spindle and epithelioid cells with hyperchromatic nuclei and prominent nucleoli. Mitotic figures including atypical mitosis were noted. The histological features were apparent malignancy. The gradual merges between epitheliod malignant cells and malignant spindle cells were seen. Immunohistochemically, both elements (spindle and epithelioid) were positive for vimentin, $\alpha$-smooth muscle actin, smooth muscle actin (HHF-35), h-caldemon, cytokeratin (CK) AE1/3, CK CAM5.2, CK WSS, CK8, CK18, CK19, p53 and Ki67 (labeling index $=57 \%$ ). They were negative for S100 protein, NSE, NCAM, synaptophysin, chromogranin, desmin, CK34BE12, CK5, CK6, CK7, CK14, CK20, CD1a, CD99, CD31, factor VIII-related antigen, CD34, HMB45, KIT, PDGFRA, CA125, CA19-9, CEA, bcl-2, CD3, CD20, CD45, CD138, and myoglobin. The tumor histologically showed epithelioid and mesenchymal features, and immunohistochmeically the tumor was positive for vimentin, smooth muscle markers, and CK. The following three possibilities of pathological diagnosis were considered; epithelioid leiomyoma, sarcomatoid carcinoma, and epithelioid carcinoma. The author stressed the expressions of various smooth muscle antigens, and diagnosed this tumor as epithelioid leiomyosarcoma. The patient refused operation and chemo-radiation. The patient showed no metastatic lesions, but died of pneumonia three years after the diagnosis at the age of 93 years. This is a rare case report of epithelioid leiomyosarcoma in UC.
\end{abstract}

Key Words: Uterus, Cervix, Epithelioid, Leiomyosarcoma, Immunohistochemistry

\section{INTRODUCTION}

The most common tumor of the uterus is leiomyoma. ${ }^{[1]} \mathrm{Al}-$ though cellular leiomyoma of uterus is common, leiomyosarcoma of uterus is rare. Most of leiomyosarcoma of uterus is ordinary one composed only of spindle cells. In making the diagnosis of leiomyosarcoma, cellular atypia, mitotic figures, atypical mitosis, necrosis, infiltrative growth, and tumor size are important. In particular, the number of mitotic figures are important. In general, the number of mitotic figures of $>$
10 per 10 high-power-fields (HPF) are considered malignant, and those $<5$ per $10 \mathrm{HPF}$ as benign in uterine smooth muscle tumors, with $<5>10$ per 10 HPF intermediate. ${ }^{[1,2]}$ However, these criteria differs among the organs in which leiomyosarcoma develops, and above mentioned other factors should be considered. ${ }^{[1,2]}$

Leiomyosarcoma is defined as a malignant tumor composed of cells showing distinct smooth muscle features. ${ }^{[1,2]}$ Epithelioid leiomyosarcoma (EL) is a variant of leiomyosarcoma,

\footnotetext{
*Correspondence: Tadashi Terada; Email: piyo0111jp@yahoo.co.jp; Address: Department of Pathology, Shizuoka City Shimizu Hospital, Miyakami 1231 Shimizu-Ku, Shizuoka, Japan.
} 
and this entity has been well recognized in soft tissues, uterus and other sites. ${ }^{[1,3]}$ There are no descriptions of EL in WHO blue bocks of soft tissue tumors, ${ }^{[2]}$ but WHO blue book of female genital organs ${ }^{[1]}$ mentioned the category of epithelioid variant of leiomyosarcoma. In general, EL is regarded as leiomyosarcoma with prominent epithelioid features. ${ }^{[4-6]}$

Most of smooth muscle tumors of uterus develop in uterine body, but they are very rare in uterine cervix (UC). To date, there have been only a few reports ${ }^{[7-9]}$ of EL in the UC in the literature. ${ }^{[7]}$

\section{CASE REPORT}

A 90-year-old woman consulted our hospital because of abnormal uterine bleedings. Blood laboratory data showed mild increase of liver and ductal enzymes, mild anemia, mild leukocytosis, mild elevation of C-reactive protein, mild in-
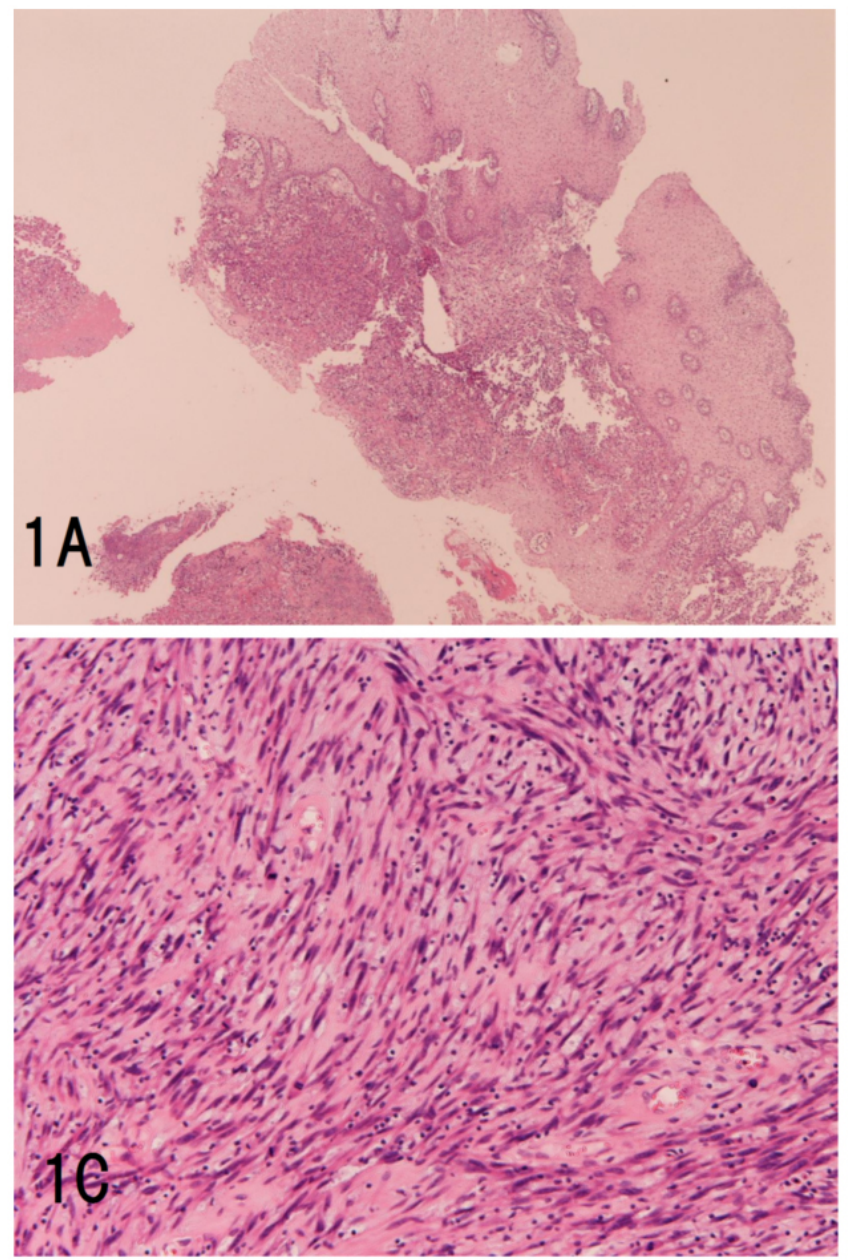

crease in blood urea nitrogen, and mild hyperuricemia. Urine data showed 1+ proteinuria. The tumor markers were within normal ranges.

Colposcopic examination revealed erosions of the cervix, and a biopsy was taken. It showed proliferation of atypical spindle and epithelioid cells with hyperchromatic nuclei and prominent nucleoli (see Figures 1A-1C). Mitotic figures including atypical ones were noted (see Figures 1B-1C). The mitotic index was 23 per $10 \mathrm{HPF}$. The histological features were apparently malignant in both epithelioid (see Figure 1B) and spindle areas (see Figure 1C). The gradual merges between epithelioid malignant cells and malignant spindle cells were seen. In some areas, malignant cells with clear vacuolated cytoplasm similar to the transverse sections of muscle bundles or to leiomyoblasts were seen (see Figure 1D).
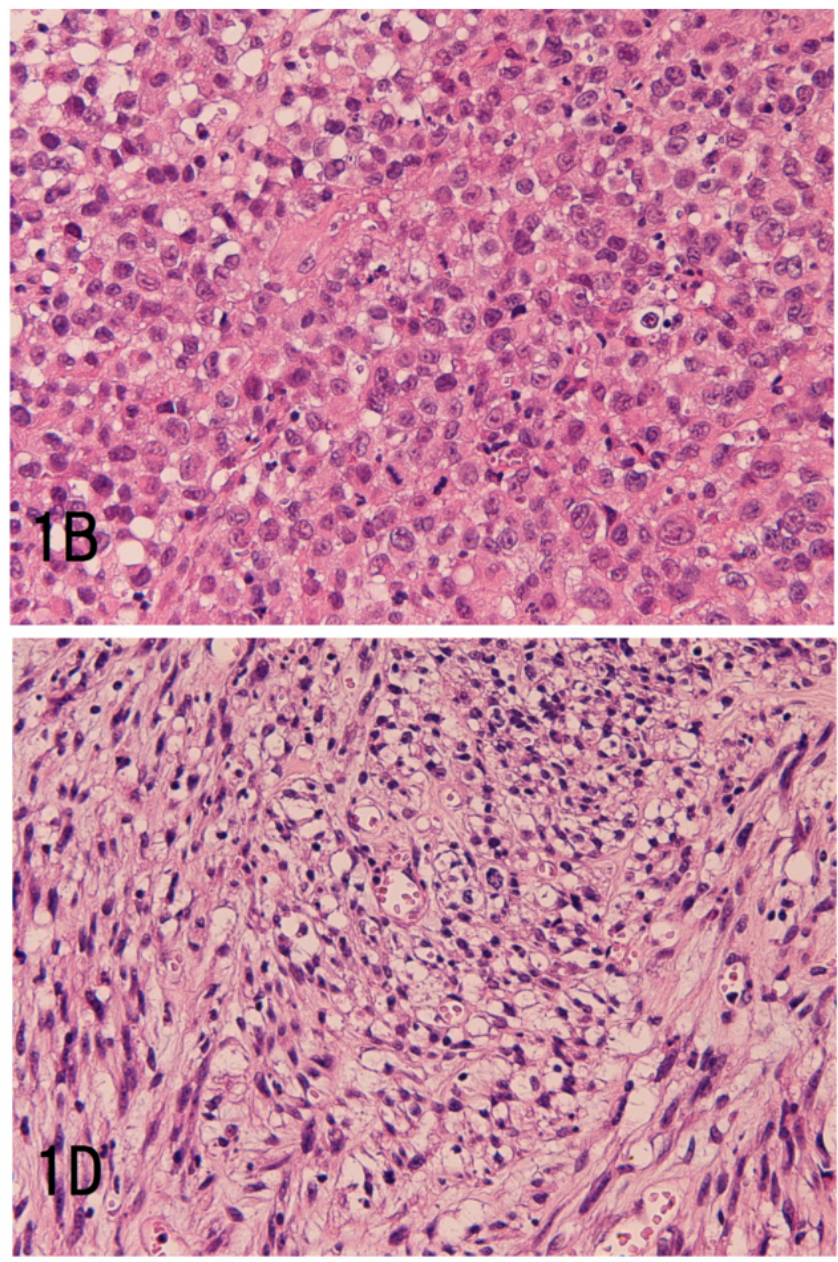

Figure 1. Histology of epithelioid leiomyosarcoma of the uterine cervix

A: Low power view of the biopsy. Under the squamous epithelium, proliferation of malignant epithelioid cells and spindle cells is seen. HE, $\times$ 40. B: High power view. The malignant tumor cells are epithelioid in this area. Note numerous mitosis. HE, $\times 200$. C: High power view. The tumor is spindle and its features are sarcoma. HE, $\times 200$. D: In some areas, epithelioid cells with cytoplasmic clear vacuolation are seen. They may represent leiomyoblasts or transverse section of muscular bundles. HE, $\times 200$. 
An immunohistochemical study was performed with the use of Dako Envision method as previously reported. ${ }^{[10-16]} \mathrm{Im}$ munohistochemically, the both elements (spindle and epithelioid) were positive for vimentin (see Figure 2A), $\alpha$-smooth muscle actin (see Figure 2B), smooth muscle actin (HHF-35) (see Figure 2C), h-caldemon (see Figure 2D), cytokeratin (CK) AE1/3, CK CAM5.2, CK WSS, CK8 (see Figure 2E), CK 18, CK19, p53 (see Figure 2F) and Ki67 (labeling index
$=57 \%)$. They were negative for S100 protein, NSE, NCAM, synaptophysin, chromogranin, desmin, CK34BE12, CK5, CK6, CK7, CK14, CK20, CD1a, CD99, CD31, factor VIIIrelated antigen, CD34, HMB45, KIT, PDGFRA, CA125, CA19-9, CEA, bcl-2, CD3, CD20, CD45, CD138, and myoglobin. That is, the tumor histologically showed epithelioid and mesenchymal tumor and immunohistochmeically the tumor showed vimentin, smooth muscle markers, and CK.
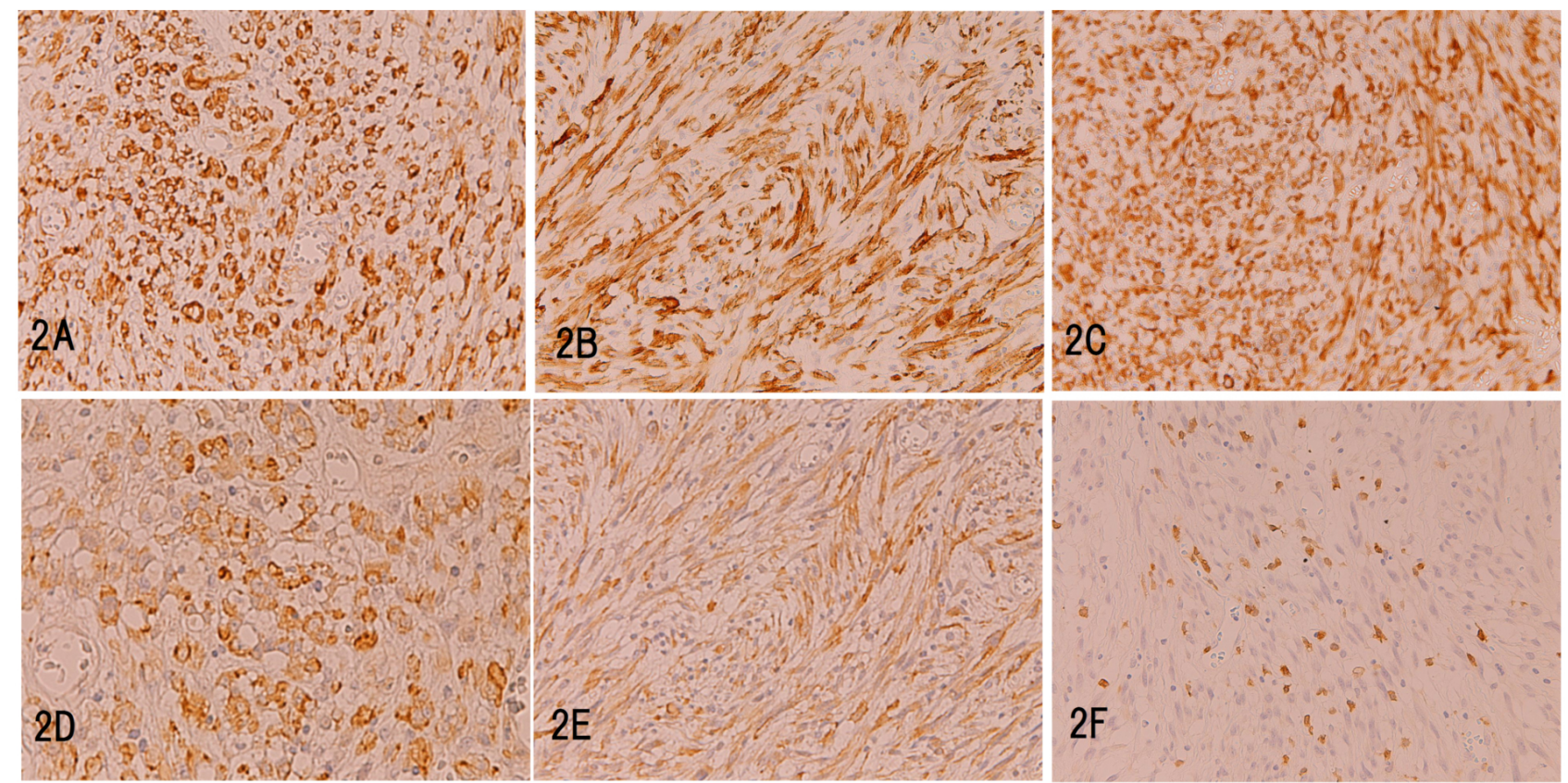

Figure 2. Immunohistochemistry of epithelioid leiomyosarcoma of the uterine cervix

The both tumor elements (spindle and epithelioid) were positive for vimentin $(A), \alpha$-smooth muscle actin $(B)$, smooth muscle actin $(H H F-35)(C)$, h-caldemon $(D)$, cytokeratin $8(E)$, and $p 53(F)$. A-F: $\times 200$.

The pathological diagnosis was very difficult. Finally, the following three possibilities were considered; EL, sarcomatoid carcinoma, and epithelioid carcinoma. The author stressed the expressions of various smooth muscle antigens, and diagnosed this tumor as EL.

The patient refused operation and chemo-radiation therapy; therefore the patient was superficially treated only by followup. The patient showed no metastatic lesions, but died of pneumonia three years after the diagnosis at the age of 93 years.

\section{Discussion}

The pathological diagnosis of the present tumor is very difficult. The histology showed spindle cell areas and epithelioid areas. The epithelioid areas were similar to the transverse sectional appearances of the smooth muscle bundles. Immunohistochemically, the tumor showed epithelial differentiation (CKs), mesenchymal differentiation (vimentin), and smooth muscle differentiation (smooth muscle antigens). Thus, the differential diagnoses of EL, sarcomatoid carcinoma and epithelioid carcinoma seem sufficient and appropriate.

Epithelioid sarcoma occurs mostly in the extremity and shows characteristic granulomatous appearances with mild atypia. The present tumor is different from this classical epithelioid sarcoma. Recently, proximal-type epithelioid sarcoma was advocated. This variant is located centrally, and has much more atypia and poor biological behaviors. ${ }^{[17-19]}$ Although the diagnosis is not complete, the author thinks that the present tumor is not this variant of epithelioid sarcoma because there have been no reports that showed smooth muscle antigens in this variant, and angiomatoid form and classical form of epithelioid sarcomas.

Sarcomatoid carcinoma rarely occurs in the uterus. ${ }^{[20-23]}$ Almost all cases of this neoplasm shows squamous cell carcinoma with sarcomatous changes, and there were no descriptions of the presence of smooth muscle antigens. In the 
current case, the cervical squamous epithelium was normal and the tumor did not show any features of squamous cell carcinoma. In addition, the present case showed some smooth muscle antigens. Therefore, it can be concluded that the present tumor is not sarcomatous or spindle cell carcinoma of uterus.

The last possibility that the present tumor is EL is most likely. The presence of $\alpha$-smooth muscle actin, smooth muscle actin (HHF-35), and h-caldesmon is highly suggestive of smooth muscle differentiation. The histological features are also strongly suggestive of EL. Thus, it can be concluded that the present tumor is EL of UC.

In some EL, HMB45 and Pecoma features are seen. ${ }^{[3]}$ In the present case, the tumor showed no perivascular endothelial patterns, and was immunohistochemically negative for CD1a and HMB45. Therefore, the present tumor is not this variant of EL.

Immunohistochemically, the present EL showed CK profile mainly of low molecular weight $\mathrm{CK}$. The positive p53 suggest the mutations of p53 gene. The high Ki-67 labeling suggests high cell proliferation. Both p53 and Ki-67 suggest malignant potential of the present EL. The negative S100 protein, NSE, NCAM, synaptophysin, chromogranin in the present study shows that the present EL shows no neuroendocrine differentiation. The negative CD99 suggest that the epithelioid cells are not Ewing/PNET. The negative CD31, CD34 and factor VIII-related antigen suggests that the present tumor shows no differentiation of vascular endothelial cells. The absence of immunoreactive CD3, bcl-2, C20, CD138, and CD45 indicate that the tumor is not lymphoma or plasmacytoma. The negative CK14 suggests that the present tumor is not myoepithelial or basal cell-related neoplasms. The negative S100 protein and melanosome
(HMB45) suggest that the tumor is not melanoma. The negative KIT and PDGFRA suggest that the present tumor is not KIT or PDGFRA-related tumor such as GIST and small cell carcinoma. The negative CA125, CA19-9, and CEA suggest that the tumor shows no adenocarcinomatous differentiation. The negative myoglobin suggests that the tumor is not rhabdomyosarcoma. The negative desmin is difficult to understand. In general desmin is thought to label striated and smooth muscles. However, it is well known that desmin has high specificity but has low sensitivity. Thus, negative desmin does not exclude the smooth muscle nature of the present EL.

The origin of uterus leiomyoma and leiomyosarcoma is myometrium. The present EL may de derived from myometrium in the UC. The pathogenesis of EL of UC should be elucidated.

\section{Conclusion}

In conclusion, the author presented a rare case of EL of the UC. The tumor histologically consisted of malignant spindle cells areas and malignant epithelioid cells areas. Immunohistochemnically, both areas showed vimentin, low-molecular weight $\mathrm{CK}$, and smooth muscle antigens ( $\alpha$-smooth muscle actin, smooth muscle actin [HHF-35], and h-caldesmon). The smooth muscle antigens and meticulous histological observation lead to the correct diagnosis.

\section{Consent}

Informed content was obtained from the patient. The publication was approved by Ethical Committee of the Hospital, although the Committee consisted of non-ethical persons.

\section{CONFlicts OF INTEREST Disclosure}

The author declares that he has no conflicts of interest.

\section{REFERENCES}

[1] Hendrickson MR, Tavassoli FA, Kempson RL, et al. Mesenchymal tumours and related lesions. In: Tavassoéli FA and Devilee P eds: World Health Organization Classification of Tumours. Pathology and Genetics of Tumours of the Breast and Female Genital Organs. Lyon: IARC Press; 2004. 233-244 p.

[2] Evans HL, Shipley J. Leiomyosarcoma. In: Fletcher CDM, Unni KK Hertens F eds: Would Health Organization Classification of Tumours. Pathology and genetics of tumours of soft tissue and bone. Lyon: IARC Press; 2002. 131-134 p.

[3] Silva EG, Deavers MT, Bodurka DC, et al. Uterine epithelioid leiomyosarcomas with clear cells: reactivity with HMB-45 and the concept of PEComa. Am J Surg Pathol. 2004; 28: 244-249. PMid: 15043315. http://dx.doi.org/10.1097/00000478-2 00402000-00013
[4] Prayson RA, Goldblum JR, Hart WR. Epithelioid smooth-muscle tumors of the uterus: a clinicopathologic study of 18 patients. Am J Surg Pathol. 1997; 21: 383-391. PMid: 9130984. http: //dx.doi.org/10.1097/00000478-199704000-00003

[5] Suster S. Epithelioid leiomyosarcoma of the skin and subcutaneous tissue. Clinicopathologic, immunohistochemical, and ultrastructural study of five cases. Am J Surg Pathol. 1994; 18: 232-240. PMid: 8116792. http://dx.doi.org/10.1097/00000478-199 403000-00002

[6] Kato K, Arai K, Tanaka Y, et al. Epithelioid leiomyosarcoma in a non-immunocompromised infant: additional differential diagnosis of pediatric "round cell tumors". Mod Pathol. 2000; 13: 1156-1160. PMid: 11048812. http://dx.doi.org/10.1038/modpathol.3 880213

[7] Toyoshima M, Okamura C, Niikura H, et al. Epithelioid leiomyosar- 
coma of the uterine cervix: a case report and review of the literature. Gynecol Oncol. 2005; 97: 957-960. PMid: 15890394. http://dx.doi.org/10.1016/j.ygyno.2005.02.028

[8] Gotoh T, Kikuchi Y, Takano M, et al. Epithelioid leiomyosarcoma of the uterine cervix. Gynecol Oncol. 2001; 82: 400-405. PMid: 11531304. http://dx.doi.org/10.1006/gyno.2001.6288

[9] Chargui R, Bouzid T, Khomsil F, et al. Epithelioid leiomyosarcoma of the uterine cervix: two cases. Tunis Med. 2007; 85: 963-936. In French. PMid: 19166150.

[10] Terada T, Endo K, Maeta H, et al. Epithelioid leiomyosarcoma with osteoclast-like giant cells in the rectum. Arch Pathol Lab Med. 2000; 124: 438-440. PMid: 10705403.

[11] Terada T, Kawaguchi M, Furukawa K, et al. Minute mixed ductalendocrine carcinoma of the pancreas with predominant intraductal growth. Pathol Int. 2002; 52: 740-746. PMid: 12685552. http: //dx.doi.org/10.1046/j.1440-1827.2002.01416.x

[12] Terada T, Takeuchi T, Taniguchi M. Hepatobiliary cystadenocarcinoma with cystadenoma elements of the gall bladder in an old man. Pathol Int. 2003; 53: 790-795. PMid: 14629305. http: //dx.doi.org/10.1046/j.1440-1827.2003.01559.x

[13] Terada T, Tanigichi M. Intraductal oncocytic papillary neoplasm of the liver. Pathol Int. 2004; 54: 116-123. PMid: 14720143. http://dx.doi.org/10.1111/j.1440-1827.2004.01594.x

[14] Terada T, Kawaguchi M. Primary clear cell adenocarcinoma of the peritoneum. Tohoku J Exp Med. 2005; 206: 271-275. PMid: 15942157. http://dx.doi.org/10.1620/tjem.206.271

[15] Terada T. Extramuscular subcutaneous fibrolipoma containing foci of striated muscle cells: a hitherto unreported condition. Int J Clin Exp Pathol. 2013; 6: 113-115. PMid: 23236552.
[16] Terada T. Vascular leiomyoma of the lung arising from pulmonary artery. Int J Clin Exp Pathol. 2013; 6: 97-99. PMid: 23236548.

[17] Guillou 1, Kaneko Y. Epitheliod sarcoma. In Fletcher CDM, Unni K, Mertens F eds: World Heath Organization of Tumours. Pathology and genetics of tumours of soft tissue and bone. Lyon: IARC Press; 2002. 205-207 p.

[18] Guillou L, Wadden C, Coindre JM, et al. "Proximal-type" epithelioid sarcoma, a distinctive aggressive neoplasm showing rhabdoid features. Clinicopathologic, immunohistochemical, and ultrastructural study of a series. Am J Surg Pathol. 1997; 21: 130-146. PMid: 9042279. http://dx.doi.org/10.1097/00000478-199 702000-00002

[19] Hasegawa T, Matsuno Y, Shimoda T, et al. Proximal-type epithelioid sarcoma: a clinicopathologic study of 20 cases. Mod Pathol. 2001; 14: 655-663. PMid: 11454997. http://dx.doi.org/10.1038/m odpathol. 3880368

[20] Terada T. Sarcomatoid squamous cell carcinoma of the uterixine cervix. Arch Gynecol Obstet. 2010; 282: 231-232. PMid: 20180127. http://dx.doi.org/10.1007/s00404-010-1409-1

[21] Rodrigues L, Santana I, Cunha T, et al. Sarcomatoid squamous cell carcinoma of the uterine cervix: case report. Eur J Gynaecol Oncol. 2000; 21: 287-289. PMid: 10949396.

[22] Kumar M, Bahl A, Sharma DN, et al. Sarcomatoid squamous cell carcinoma of uterine cervix: pathology, imaging, and treatment. J Cancer Res Ther. 2008; 4: 39-41. PMid: 18417901. http: //dx.doi.org/10.4103/0973-1482.39604

[23] Pang LC. Sarcomatoid squamous cell carcinoma of the uterine cervix with osteoclast-like giant cells: report of two cases. Int J Gynecol Pathol. 1998; 17: 174-177. PMid: 9553816. http: //dx.doi.org/10.1097/00004347-199804000-00014 